\title{
EFEK ANTI INFLAMASI KITOSAN DARI CANGKANG UDANG PANTAI TRISIK PADA TIKUS MODEL RHEUMATOID ARTHRITIS
}

\section{THE ANTI-INFLAMMATORY EFFECTS OF CHITOSAN OF SHRIMP SHELL OF TRISIK COASTAL IN RHEUMATOID ARTHRITIC RATS MODEL}

\author{
Nurul Hanifah, Endang Darmawan \\ Fakultas Farmasi, Universitas Ahmad Dahlan \\ Jln. Prof. Dr. Soepomo, Janturan, Yogyakarta, Telp. (0274) 379418 \\ Email: enddarmawan@gmail.com
}

Submitted : 04-09-2015

Reviewed : 05-09-2015

Accepted: 25-11-2015

\begin{abstract}
ABSTRAK
Penelitian ini bertujuan untuk mengetahui pengaruh pemberian kitosan sebagai anti inflamasi pada rheumatoid arthritis dilihat dari penurunan volume udem pada kaki tikus menggunakan pletismometer. Kitosan yang diisolasi dari limbah cangkang udang Pantai Trisik diberikan secara oral mulai hari ke-17 sampai 32 yang disuspensikan dengan CMC 0,5\%. Rancangan penelitian pengamatan berulang digunakan dalam uji anti inflamasi yang dilakukan pada model tikus rheumatoid arthritis yang diinduksi dengan menggunakan Complete Freund's Adjuvant (CFA) pada hari ke-1 sampai 16. Penelitian dilakukan dengan membagi tikus ke dalam 5 kelompok $(n=6)$, yakni kontrol normal, kontrol positif, kontrol negatif, 1 kelompok diberikan suspensi kitosan dengan dosis $50 \mathrm{mg} / 200$ gram BB dan sisanya diberikan suspensi kitosan dengan dosis $100 \mathrm{mg} / 200$ gram BB. Pengukuran penurunan volume udem kaki tikus dilakukan setiap 3 hari setelah hari ke-17, kemudian dianalisis menggunakan general linear repeated measure test $(\mathrm{p}<0,05)$. Hasil penelitian menunjukkan bahwa suspensi kitosan dengan dosis $100 \mathrm{mg} / 200$ gram BB $(142,66 \%)$ menurunkan volume udem yang lebih baik dibandingkan dengan suspensi kitosan dengan dosis $50 \mathrm{mg} / 200$ gram BB (117,23\%) pada telapak kaki tikus yang terkena arthritis. Berdasarkan data penelitian yang telah dilakukan maka dapat diambil kesimpulan bahwa kitosan yang diolah dari cangkang udang Pantai Trisik dapat digunakan sebagai anti inflamasi pada tikus model rheumatoid arthritis.
\end{abstract}

Kata kunci: kitosan, rheumatoid arthritis, inflamasi, Complete Freund`s Adjuvant (CFA).

\section{ABSTRACT}

This research was conducted to investigate the effect of chitosan as anti-inflammatory in rheumatoid arthritic in reduction of paw edema using plethysmometer. Chitosan was isolated from the shrimp shell on the Trisik Coastal were administered orally on $17-32^{\text {th }}$ day with CMC $0,5 \%$. This research using repeated measure design. To evaluate anti-inflammatory effect of the suspension, an arthritic rats model was developed using Complete Freund's Adjuvant (CFA) on $1-16^{\text {th }}$ day. In addition, the research was divided into 5 groups $(n=6)$ including normal control groups, positive control groups, negative control groups, 1 group were treated by chitosan suspension at $50 \mathrm{mg} / 200$ gram BW doses and the other group were treated by chitosan suspension at $100 \mathrm{mg} / 200$ gram BW doses. The reduction of paw edema were determined every 3 day after $17^{\text {th }}$ days then analyzed using general linear repeated measure test $(\mathrm{p}<0,05)$. The results showed that paw edema of arthritic rats were evidently decreased by chitosan suspension at $100 \mathrm{mg} / 200$ gram BW doses $(142,66 \%)$ better than chitosan suspension at $50 \mathrm{mg} / 200$ gram BW doses $(117,23 \%)$. In conclusion, the chitosan from shrimp shell of Trisik coastal is found to be effective as anti-inflammatory in rheumatoid arthritic rats model.

Keywords: chitosan, rheumatoid arthritis, inflammation, Complete Freund's Adjuvant (CFA) 


\section{PENDAHULUAN}

Limbah cangkang udang yang dihasilkan dari 699.000 ton udang yang ditargetkan dapat diproduksi pada tahun 2014 (Anonim, 2014) dapat mencapai 454.350 ton atau sekitar 60-70\% dari berat total udang. Limbah tersebut dapat diolah menjadi kitosan yang diduga mampu mengobati penyakit rheumatoid arthritis karena memiliki struktur menyerupai glukosamin yang sering digunakan dalam pengobatan penyakit arthritis (Olivier \& Jean-Yves, 2007).

Menurut American Collage of Rheumatology and Marketing Committee (2012), rheumatoid arthritis menyerang lebih dari 1,3 Milyar orang Amerika dengan 75\% di antaranya merupakan wanita. Prevalensi penyakit sendi berdasar diagnosis atau gejala di Indonesia sebanyak 24,7\% dimana yang tertinggi berada di Nusa Tenggara Timur dengan persentase sebesar 33,1\% (Anonim, 2013). Rheumatoid arthritis merupakan penyakit autoimun yang bersifat inflamasi kronik-sistemik yang menyebabkan hipertrofi (bengkak) dan penebalan membran pada synovium oleh lapisan jaringan granular yang membentuk panus. Pada akhirnya panus menyebabkan deformitas sehingga terjadi kekakuan dan kehilangan fungsi sendi secara permanen (Mulyaningsih \& Darmawan, 2006).

Pengobatan pada penyakit arthritis sampai saat ini masih menggunakan obat-obat sintetik yang memiliki banyak efek samping seperti disease-modifying antirheumatic drugs (DMARD's), analgetika, dan kortikosteroid (Tjay \& Rahardja, 2002). Sebanyak 10\% pasien mengalami diare, mual, muntah, dan toksisitas hematologi (terutama trombositopenia) pada pasien yang menggunakan methotrexate (Dipiro et al.,2005). Kombinasi terapi leflunomide dengan methotrexate memiliki resiko yang lebih tinggi yaitu mengakibatkan gangguan fungsi hati sebesar 31,5\% (Olsen \& Stein, 2004).

Pengobatan individu dan promosi gaya hidup sehat serta manajemen diri untuk mengoptimalkan hasil pengobatan pada pasien rheumatoid arthritis menggunakan obat tradisional merupakan salah satu cara untuk meningkatkan kesadaran masyarakat terhadap bahaya arthritis sebagai sebuah penyakit yang dapat menyebabkan kecacatan yang ditekankan oleh The National Arthrtis Action Plan (NAAP) sebagai suatu Public Health Strategy (Anonim, 2004).

Berdasarkan data penelitian sebelumnya tentang kitosan yang dapat diolah dari cangkang udang, diduga kitosan dapat digunakan sebagai anti inflamasi pada rheumatoid arthritis. Tujuan penelitian ini adalah untuk mengetahui kemampuan kitosan dalam menghambat proses terjadinya inflamasi pada rheumatoid arthritis.

\section{METODE PENELITIAN}

Bahan dan Peralatan

Bahan yang digunakan dalam penelitian ini adalah kitosan yang diolah dari limbah cangkang udang, Complete Freund's Adjuvant (CFA) yang mengandung Mycobacterium butyricum, tablet salut Natrium diklofenak $50 \mathrm{mg}$ sebagai reference drug (kontrol positif) dan aquades. Hewan uji yang digunakan adalah tikus jantan galur Sprague Dawley (SD), umur 1 bulan, berat badan 150-250 gram yang diberi pakan AD2 dan minum ad-libitum. Fourier Transform Infrared (FT-IR) dan FTIRhydroulic presser untuk identifikasi kitosan dan plethysmometer untuk uji anti inflamasi pada hewan uji.

Tahapan dan Proses Penelitian

Tahapan dan proses penelitian secara sistematis dibagi kedalam 3 tahapan sebagai berikut.

1. Isolasi kitosan dari kulit udang halus menggunakan metode deproteinasi, demineralisasi, depigmentasi, dan deasetilasi (Salami, 1998).

2. Identifikasi kitosan dengan menghitung Derajat Deasetilasi (DD) dari spektra infrared (IR) menggunakan FT-IR (Khan et al, 2002; Skoog, 1999).

3. Pengujian adjuvant-Induced Arthritic dan pengujian anti inflamasi pada tikus (Mulyaningsih \& Darmawan, 2006). 
Analisis Hasil

Data yang dikumpulkan berupa volume udem sebelum dan selama perlakuan berlangsung digunakan untuk menghitung persentase kenaikan volume udem tiap waktu seperti yang tertera pada Persamaan 1 (Mansjoer, 1997).

$$
\% \text { Kenaikan Volume Udem }(\text { KVU })=100 \% \mathbf{x} \frac{\text { vt-Vo }}{\text { Vo }}
$$

Dimana Vt merupakan volume telapak kaki tikus pada waktu tertentu, sedangkan $\mathrm{V}_{0}$ merupakan volume telapak kaki tikus sebelum pemberian obat. Dari persentase kenaikan volume udem kemudian dihitung harga Area Under Curve (AUC) yang nantinya digunakan untuk menghitung nilai persentase daya anti inflamasi (DAI) dalam bentuk persentase.

$$
\% \text { Daya Anti Inflamasi }(D A I)=100 \% x \frac{A U C k-A U C p}{A U C k}
$$

Rata-rata dari persentase DAI yang telah diperoleh dianalisis secara statistik menggunakan general linear model repeated measure design dengan taraf kepercayaan $95 \%(\mathrm{p}<0,05)$.

\section{HASIL DAN PEMBAHASAN}

Penelitian awal dilakukan dengan melakukan sintesis kitosan dari kitin yang terkandung dalam limbah cangkang udang yang diperoleh dari Pantai Trisik di Kabupaten Kulonprogo, Yogyakarta. Kitin diisolasi melalui 3 tahap, yaitu deproteinasi, demineralisasi dan depigmentasi. Proses deproteinasi bertujuan untuk memutuskan ikatan antara protein dan kitin, dengan cara menambahkan Natrium hidroksida (basa kuat) pada suhu tinggi yang diharapkan terjadi perubahan $\mathrm{pH}$, sehingga dapat mengendapkan protein (terjadi praesipitasi) (Zulfikar \& Ratnadewi, 2006). Terbentuk sedikit gelembung pada permukaan larutan dan terjadi pengentalan larutan ketika proses pencampuran dengan $\mathrm{NaOH} 3,5 \%$ mengindikasikan adanya kandungan protein yang terlepas dan berikatan dengan ion $\mathrm{Na}^{+}$. Proses demineralisasi menggunakan asam klorida bertujuan untuk memisahkan mineral yang terkandung sebagai filtrat, seperti Magnesium, Kalium, Natrium, Kalsium, Fosfor, Besi, dan Seng yang ditunjukkan dengan terbentuknya banyak buih dan gelembung udara karena terlepasnya gas $\mathrm{CO}_{2}$ dan $\mathrm{H}_{2} \mathrm{O}$ (Yuliusman \& Adelina, 2010), sedangkan proses depigmentasi menggunakan larutan Natrium hipoklorit $(\mathrm{NaOCl})$ bertujuan untuk menghilangkan warna (pigmen) yang terkandung (Komariah, 2013). Kitin bebas protein, mineral, dan pigmen yang dihasilkan dari ketiga tahap tersebut disintesis menjadi kitosan dengan melepaskan gugus asetilnya menggunakan $\mathrm{NaOH} 50 \%(\mathrm{~b} / \mathrm{v}$ ) pada suhu tinggi, dimana pada kondisi tersebut reaksi berlangsung secara efektif (Yuliusman \& Adelina, 2010).

Identifikasi kitosan dilakukan dengan menghitung Derajat Deasetilasi (DD) dalam persen (\%) menggunakan persamaan yang dikemukakan oleh Domszy dan Robert pada Persamaan 3 (Khan, 2002).

$$
\% \text { Derajat Deasetilasi }(D D)=\left[1-\left(\frac{A_{1655}}{A_{3450}} \times \frac{1}{1,33}\right)\right] \times 100 \%
$$

Berdasarkan pembacaan spektrum infrared dari hasil analisa menggunakan FTIR dengan metode base line diperoleh data $\mathrm{A}_{1655}$ sebesar 0,03 dimana data ini merupakan data absorbansi ikatan amida yang terdapat pada bilangan gelombang $1655 \mathrm{~cm}^{-1}$, sedangkan data $\mathrm{A}_{3450}$ yang merupakan absorbansi ikatan hidroksil yang terdapat pada bilangan gelombang $3450 \mathrm{~cm}^{-1}$ diperoleh data absorbansi sebesar 0,05 (lihat juga Gambar 1). Bilangan 1,33 pada Persamaan 3 merupakan tetapan yang diperoleh dari perbandingan $\mathrm{A}_{1655} / \mathrm{A}_{3450}$ untuk kitosan dengan asetilasi penuh atau total.

Kitosan dengan derajat deasetilasi besar menunjukkan banyaknya gugus asetil kitin yang diubah menjadi gugus amino. Berdasarkan perhitungan menggunakan Persamaan 3 maka dapat diketahui bahwa derajat deasetilasi kitosan yang didapatkan sebesar 59,10\%. Meski kitosan yang beredar umumnya memiliki derajat deasetilasi 70-90\%, akan tetapi kitosan yang telah berhasil disintesis telah 
memenuhi spesifikasi minimum derajat deasetilasi kitosan, yaitu lebih dari 50\% (Yuliusman \& Adelina, 2010). Hal ini menunjukkan proses deasetilasi yang dilakukan kurang maksimal.

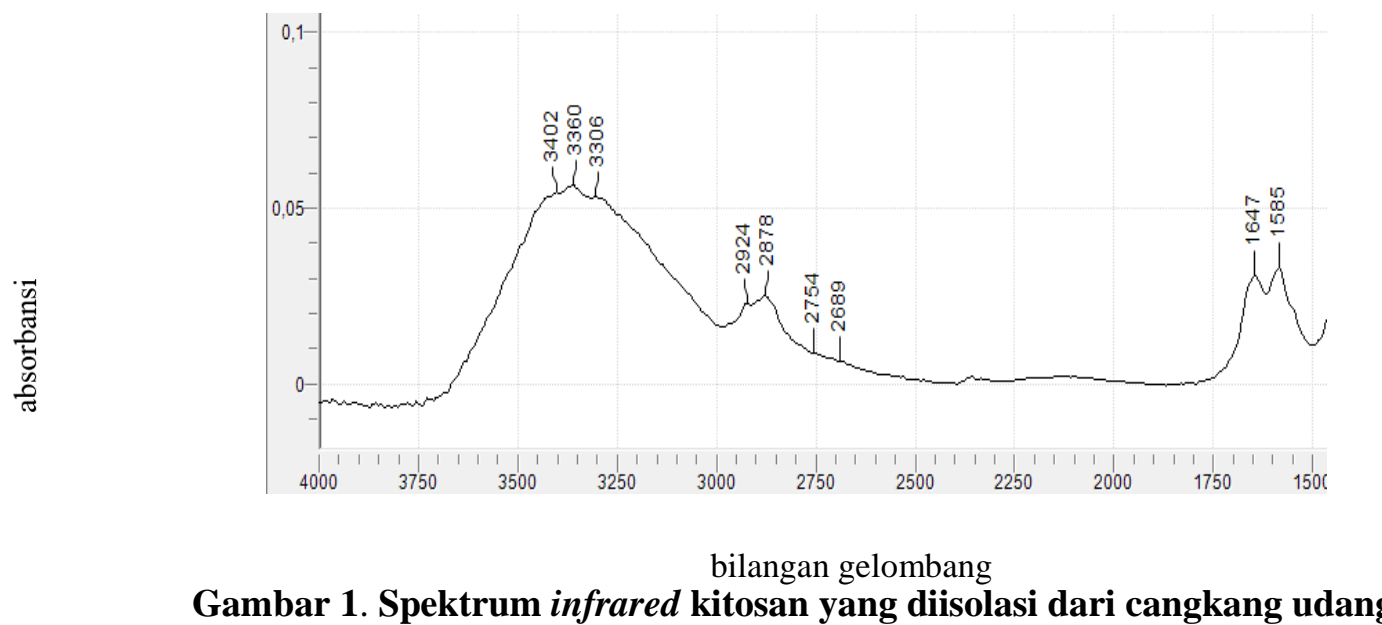

Hasil Pengujian Aktivitas Anti Inflamasi Kitosan

Keberhasilan induksi arthritis dapat dilihat dari persen insidensi arthritis yang menunjukkan bahwa semua tikus telah memiliki nilai indeks arthritis lebih dari 1 pada hari ke-17 kecuali pada kelompok normal yang tidak diinduksi Complete Freund's Adjuvant (CFA) (Smith, 2000). Induksi arthritis dilakukan dengan menyuntikkan CFA pada kaki kanan tikus secara sub plantar. Apabila penginduksian dilakukan secara intradermal maka udem yang terjadi bukan karena perkembangan arthritis namun karena terjadi emboli larutan CFA sehingga akan menimbulkan bias nilai volume udem. CFA yang berisi bakteri Mycobacterium butyricum yang dilemahkan bekerja sebagai penstimulus imun yang memicu terjadinya akumulasi limfosit, pembentukan kompleks imun yang mengaktifkan komplemen, prostaglandin, anoin superoksid serta berbagai enzim yang dapat mendegradasi tulang yang akan menyebabkan destruksi sendi, nyeri, dan inflamasi (Isbagio, 1992).

Gambar 2 menunjukkan volume udem telapak kaki tikus meningkat setelah induksi CFA, kemudian menurun sebanding dengan waktu setelah tikus diberikan perlakuan dengan dua variasi dosis kitosan. Tikus pada kelompok kontrol negatif yang hanya mendapatkan perlakuan larutan salin menunjukkan grafik terbesar dibanding kelompok lainnya. Peningkatan volume udem ini membuktikan bahwa telah terjadi suatu inflamasi akibat adanya penyakit rheumatoid arthritis.

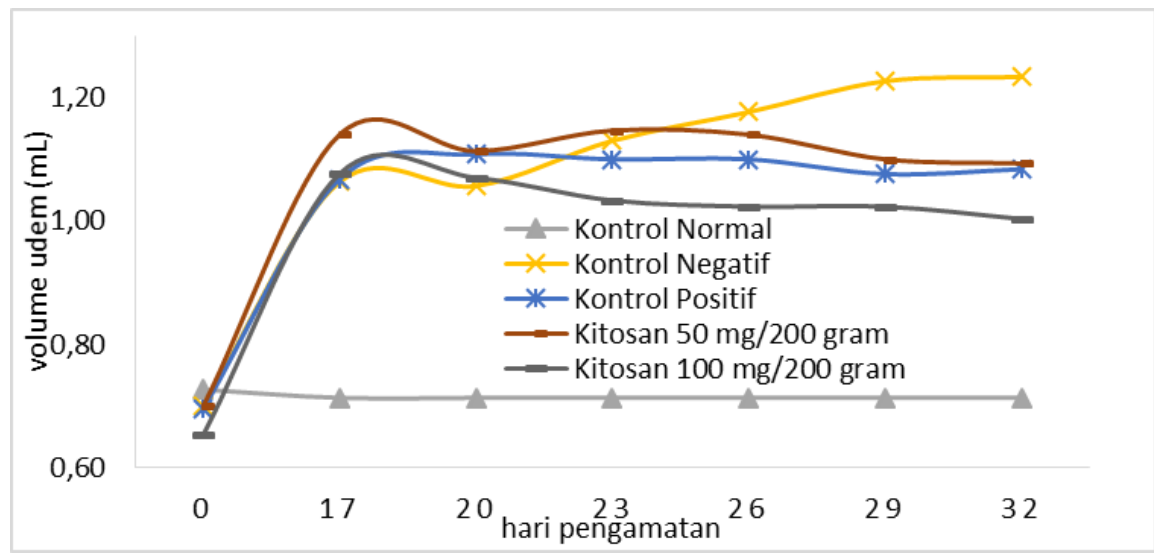

Gambar 2. Grafik volume rata-rata telapak kaki tikus yang diinduksi Complete Freund's Adjuvant (CFA) setelah pemberian kitosan selama 15 hari

Kemampuan suatu bahan dalam mengurangi udem pada kaki hewan uji dinyatakan sebagai daya anti inflamasi (DAI). Persentase daya anti inflamasi diperoleh dengan membandingkan luas daerah bawah 
kurva volume udem kelompok perlakuan dan kontrol positif dengan luas daerah bawah kurva kontrol negatif (Hidayati et al., 2008). Persentase daya anti inflamasi menunjukkan bahwa semakin besar nilai persentasenya maka semakin besar pula efek penurunan volume udem (Sutrisna et al., 2010).

Perbedaan yang signifikan terjadi pada pengukuran berulang yang dilakukan untuk mengetahui perubahan persentase kenaikan volume udem, ditunjukkan dengan nilai $\mathrm{F}(30,170)=5,28 \mathrm{p}<0,05$, sedangkan perubahan yang tidak signifikan terjadi pada perubahan persentase daya anti inflamasi kitosan sejak pengukuran ke-1 sampai dengan pengukuran ke-6 dengan nilai $F(30,170)=1,2 p>0,05$. Hasil analisis statistik hubungan antara waktu dengan perbedaan perlakuan pada masing-masing kelompok menunjukkan bahwa perubahan persentase kenaikan volume udem (dengan $F(6,34)=5,97 \mathrm{p}$ $=0,000)$ dan persentase daya anti inflamasi (dengan $\mathrm{F}(6,34)=3,49 \mathrm{p}=0,008$ ) dapat berubah secara signifikan seiring dengan adanya perubahan waktu.

Uji satatistik pada kelompok kontrol positif dan kelompok perlakuan kitosan 100 mg/200 gram BB menunjukkan perbedaan secara bermakna $(\mathrm{p}<0,05)$ dengan kelompok kontrol negatif. Data ini menunjukkan bahwa pengobatan dengan natrium diklofenak dan kitosan pada dosis tertentu dapat mengurangi udem secara signifikan dibandingkan jika tidak diberikan pengobatan. Efek natrium diklofenak dalam menurunkan volume udem tidak memberikan perbedaan yang signifikan dengan efek yang ditimbulkan oleh kitosan $100 \mathrm{mg} / 200$ gram BB, tetapi memberikan perbedaan yang signifikan dengan efek yang ditimbulkan oleh kitosan dengan dosis $50 \mathrm{mg} / 200$ gram BB. Data ini mengindikasikan efek anti inflamasi dari kitosan pada dosis $100 \mathrm{mg} / 200$ gram BB setara dengan efek dari natrium diklofenak, tetapi tidak setara dengan kitosan dengan dosis $50 \mathrm{mg} / 200$ gram BB. Jika dibandingkan diantara ketiga kelompok perlakuan yang diobati, maka kitosan dengan dosis 100 $\mathrm{mg} / 200$ gram BB memberikan efek anti inflamasi yang paling besar ditandai dengan persentase daya anti inflamasi yang paling besar di antara suspensi lainnya.

Tabel I. Persentase daya anti inflamasi pada telapak kaki tikus yang diinduksi Complete Freund's Adjuvant (CFA) setelah pemberian kitosan selama 15 hari

\begin{tabular}{lr}
\hline \multicolumn{1}{c}{$\begin{array}{c}\text { Kelompok Dosis } \\
(\mathbf{n = 6})\end{array}$} & $\begin{array}{c}\text { Daya Anti Inflamasi (\%) } \\
\pm \text { SE }\end{array}$ \\
\hline Kontrol Normal & $0,00 \pm 0,00^{\mathrm{c}}$ \\
Kontrol Negatif & $0,00 \pm 20,60^{\mathrm{c}}$ \\
Kontrol Positif (Natrium diklofenak 1 mg/200 gram BB) & $70,78 \pm 17,67^{\mathrm{a}, \mathrm{b}}$ \\
Kitosan 50 mg/200 gram BB & $117,23 \pm 18,79^{\mathrm{c}}$ \\
Kitosan 100 mg/200 gram BB & $142,66 \pm 13,03^{\mathrm{a}, \mathrm{b}}$ \\
\hline
\end{tabular}

keterangan : a. berbeda bermakna dengan kelompok kontrol normal $(\mathrm{p}<0,05)$

b. berbeda bermakna dengan kelompok kontrol negatif $(p<0,05)$

c. berbeda bermakna dengan kelompok kontrol positif $(p<0,05)$

Daya anti inflamasi yang dimiliki kitosan dapat disebabkan karena kitosan memiliki struktur menyerupai glukosamin, dimana salah satu mekanisme kerja dari glukosamin adalah dengan mengurangi produksi enzim COX-2 sehingga ekspresi dari IL-1 yang diinduksi oleh COX-2 dan NFкB pada eksplan tulang rawan dapat ditekan. Selain itu, hal ini menyebabkan berkurangnya produksi PGE2 sebagai mediator inflamasi dan mediator yang bertanggung jawab atas kematian sel kondrosit (Jerosch, 2011). Kim \& Kim (2006) manarik kesimpulan bahwa aktifitas penghambatan yang dilakukan kitosan merupakan penghambatan yang non kompetitif.

\section{KESIMPULAN}

Kitosan yang diolah dari limbah cangkang udang Pantai Trisik memiliki efek anti inflamasi pada rheumatoid arthritis ditinjau dari penurunan volume udem telapak kaki belakang tikus yang terinduksi Complete Freund's Adjuvanti (CFA). Kitosan dengan dosis 100 mg/200 gram BB memiliki daya anti 
inflamasi yang lebih baik dibandingkan dengan kitosan pada dosis $50 \mathrm{mg} / 200$ gram BB dilihat dari persentase daya anti inflamasinya yakni sebesar $142,66 \%$.

\section{UCAPAN TERIMA KASIH}

Terima kasih disampaikan kepada PT. Indofood Sukses Makmur Tbk. yang telah mendanai pelaksanaan penelitian ini melalui program Indofood Riset Nugraha 2014-2015 berdasarkan pada perjanjian kerjasama penelitian No. SKE/021/CC/V/2014.

\section{DAFTAR PUSTAKA}

American College of Rheumatology \& Marketing Commitee 2012, Rheumatoid Arthritis, American College of Rheumatology and Marketing Committee, Atlanta.

Anonim 2004, Evidance to Support the National Action Plan for Osteoarthritis, Rheumatoid Arthritis and Osteoporosis, Australian Government Departement of Health and Ageing, Canberra.

Anonim 2013, Riset Kesehatan Dasar (RISKESDAS 2013), Kementrian Kesehatan RI, Jakarta.

Anonim 2014, Produksi Perikanan Budidaya Mendukung Perekonomian Nasional dan Meningkatkan Kesejahteraan, [online] available at: Error! Hyperlink reference not valid. (diakses pada tanggal 20 Januari 2015).

Dipiro, J.T., Talbert, R.L., Gary, C.Y., RM, Weel, B.G., Posey, L.M. 2005, Pharmacotherapy: A pathophyciologic approach, The McGraw-Hill, USA.

Hidayati, N.A., Lityawati, S. \& Setyawan, A.D. 2008, Kandungan Kimia dan Uji Antiinflamasi Ekstrak Etanol Lantana camara L. pada Tikus Putih (Rattus norvegecus L.) Jantan, Bioteknologi, 5 (1) : 10-17.

Isbagio, H. 1995, Osteoartritis dan Artritis Reumatoid. Perbedaan Patogenesis, Gambaran Klinik dan terapi, Cermin Dunia Kedokteran, $104: 8-11$.

Khan, T.A., Peh, K.K. \& Chang, H.S. 2002, Reporting Degree of Deacetylation Vales of Chitosan; The Influence of Analitycal Methods, J.Pharm. Sci, 5 (3) : 205-212.

Kim, M. \& Kim, S. 2006, Chitooligosaccharides inhibit activation and expression of matrix metalloproteinase-2 in human dermal fibroblasts, FEBS Lett., 580 : 2661-2666.

Komariah, K. 2013, Karakterisasi kitin dan kitosan yang terkandung dalam eksoskeleton kutu beras (Staphilus oryzae), Prosiding Seminar Nasional Biologi, 10 (2).

Mansjoer, S. 1997, Efek anti radang minyak atsiri temu putih (Curcuma zedoria Rosc.) terhadap udem buatan pada tikus putih jantan galur wistar, Majalah Farmasi Indonesia, 8 : 35-41.

Mulyaningsih, S. \& Darmawan, E. 2006, Efek Anti Arthritis Pisang Ambon (Musa paradisiaca sapientum L.) dan Lidah Buaya (Aloe vera L.) terhadap Adjuvant-Induced Arthritic Pada Tikus. Biodiversitas, 7 (3) : 273-277.

Olivier, B. \& Jean-Yves, R. 2007, Glucosamine and chondroitin sulfate as therapeutic agents for knee and hip osteoarthritis, Drug and Aging, 24 (7) : 573-580.

Olsen. N.J. \& Stein. C.M. 2004, New Drugs for Rheumatoid Arthritis, N. Engl. J. Med., 350 : 2167-79.

Salami L. 1998, Pemilihan Metode Isolasi Khitin dan Ekstraksi Khitosan dari Limbah Kulit Udang Windu (Phenaus monodon) dan Aplikasinya sebagai Bahan Koagulasi Limbah Cair Industri Tekstil, Skripsi, Fakultas MIPA Universitas Indonesia, Jakarta.

Smith, F. 2000, Picrorhiza Scrophulariiflora from Traditional Use to Immunomodulatory. Dissertation, Rijksuniversiteit Utrech, Utrecht.

Sutrisna, E.M., Widyasari, D.F. \& Suprapto 2010, Uji Efek Anti Inflamasi Ekstrak Etil Asetat Buah Semu Jambu Mete (Anacardium occidentaele L.) Terhadap Edema pada Telapak Kaki Tikus Putih (Rattus norvegius) Jantan Galur Wistar yang Diinduksi Karagenin, Biomedika, 2 (1) : 33-37.

Tjay, T.H. \& Rahardja, K. 2002, Obat-Obat Penting. Khasiat, Penggunaan dan Efek-efek sampingnya, PT Elex Media Kompurindo Kelompok Gramedia, Jakarta. 
Yuliusman \& Adelina P.W. 2010, Pemanfaatan Kitosan dari Cangkang Rajungan Pada proses Adsorpsi Logam Nikel dari larutan $\mathrm{NiSO}_{4}$, Seminar Rekayasa Kimia dan Proses, ISSN: 1411-4216.

Zulfikar \& Ratnadewi, A.A.I. 2006, Isolasi dan Karakterisasi Fisikokimia-Fungsional Kitosan Udang Air Tawar (Macrobrachium sintanganse de Man.), Jurnal Teknologi Proses, 5 : 129-137. 